\title{
WOMEN IN THE MANIPURI SOCIETY: A PERSPECTIVE
}

\section{DR. KHELENA GURUMAYUM}

Assistant Professor (Stage III), Department of Political Science, Manipur University, Imphal, Manipur

\section{ABSTRACT}

Manipur is home to various ethnic groups. It is situated at the strategic triangle of northeastern parts of India. Manipur, a land with ethnic and cultural diversity, was once one of the independent kingdoms in Southeast Asia, with its own civilization, tradition and cultural heritage. The most distinctive characteristic of Manipur is the role of women in the various spheres of society. This paper aims to analyse the society of Manipur in general with special to the contributions made by women in the society. The study is based on both primary and secondary sources. This paper examines the major contributions of women in Manipur and also analyses the status of women in Manipur especially the Meitei women in the society. It gives insights into the role played by women in society especially in the Manipur valley. This study briefly examines the cultural biasness towards women in the Manipuri society. It analyses the biasness towards women in the traditions, customs, rituals in Manipur. It also gives certain suggestions on how the low status of Manipuri women despite the contributions made by women could be raised and gives equal treatment to women as par with males in the Manipuri society.

KEYWORDS: Women's Empowerment, Women's Status, Society \& Culture

Received: Apr 20, 2021; Accepted: May 10, 2021; Published: May 20, 2021; Paper Id.: IJEEFUSJUN20212

\section{INTRODUCTION}

The state of Manipur is home to various ethnic groups, it is inhabited by the Meiteis, Meiteis-Pangals, a number of different tribes and a negligible number of later migrants consisting of Punjabis, Bengalis, Nepalese, Marwaris and Bangladeshis etc. Manipur is a state under the Indian Union and is situated in the strategic triangle of northeast India which borders with Assam in the west, Nagaland in the north, Myanmar in the east and Mizoram in the south. Manipur, a land with ethnic and cultural diversity was once one of the independent kingdoms in Southeast Asia with its own civilization, tradition and cultural heritage. The Hills are inhabited by more than thirty notified Scheduled Tribes, which can be broadly categorised into two Proto-Communities: the Nagas and the Kukis.

Manipur has its own identity which can be seen in their art and culture which are famous in the world. Their rich culture and the centuries old tradition can also be depicted in their handloom woven clothes and handicrafts. The Manipuri culture is a blend of the indigenous Meitei culture based on the Sanamahi laining (Sanamahi worship) and the Indian culture, based on the Hindu religion. However, there are more than 30 majestic cultures and dances of the different tribes of Manipur as well.

The culture of Manipur is as exotic and ancient as the state itself. It is a perfect colourful mixture of the rich customs, the traditional cuisines, the music that is the main essence of Manipuri culture; the strict and vibrant customs, the world-famous dance forms and the rich history together make the most enchanting culture of the Manipuris. The fun and exciting element among the people of Manipur can be reflected in the various festivals that they observe like the Kut festival, Rath Yatra, Ningol Chakauba festival, Yaoshang festival, and many more. The 
festivals help to liven up the people of their daily chores with their music and dance. Especially, the dance that is called the Thabal Chongba (Moonlit dance) performed by both men and women is a typical dance form during the annual Yaoshang festival.

\section{METHODOLOGY}

This paper is exploratory and analytical in nature which is based on both primary and secondary sources. The major part of the study is based on secondary sources which include Books, Journals etc. And a very small portion of the study is based on primary sources by adopting an observation method like Interacting with some personalities selected on the basis of random sampling.

\section{OBJECTIVE OF THE STUDY}

- This study aims to analyse the society of Manipur in general.

- It also examines the status of women in Manipur especially the Meitei women.

- It gives insights into the role played by women in society.

- The study briefly analyses the cultural rituals including their biasness towards women in the Manipuri society.

- It analyses the traditions, customs, rituals in Manipur.

- It also gives certain suggestions on how the low status of Manipuri women could be raised and gives equal treatment to women as par with males in the Manipuri society.

\section{WOMEN'S CONTRIBUTION IN THE SOCIETY OF MANIPUR}

The most distinctive feature of Manipur is the contribution of women in the various realms of society. Manipuri women since earlier times have played significant roles in various activities of life, covering the religious, social, cultural, economic and political. Besides, they are the frontrunners in solving various social and political problems of the state. They are active in various spheres of life since the times of the Monarchical era. They are the major economic contributors in Manipur. We find some traditional political power of the market network which can paralyse the political or administrative system when needed. Captain Dun commented, "They are very industrious. The most of the work of the country except the heaviest is performed by them. It would be difficult to find a more industrious woman in India than the Manipuri". During the Monarchical era, the women of Manipur even launched agitations to review some policies of the Authorities when the policies are against the welfare of the people. One can thus see distinct overtones of female power and independence in the patrilineal society of Manipur, says Captain Dun.

The reason for the activisms of Manipuri women maybe because of some historical compulsions which necessitated the women to come forward and contribute in the various spheres of society. The historical necessity began with the introduction of Lallup system in Manipur during the Monarchical era. The Lallup system was introduced in 1074 A.D. during the time of King Loiyumba. According to this Lallup System, all the adult male members of the families in Manipur had to serve the King in the palace for ten days out of forty days. Under this system, all the male members of Manipur, which includes the Hill people who are above the age of 17 , had to render service at the palace. This was a compulsion for all the male members of the society to attend the Royal Palace for ten days out of forty days. And also during the time of war, all the adult males had to render military services and in normal times, they had to work for the 
economic development of the state. The menfolk used to accompany the King in his warfare against the neighbouring princely states. For instance, during the Seven Years Devastation (Chahi Taret Khuntakpa) in the history of Manipur, the war fought between Manipur and Burma (Manipur-Burma War 1819) which lasted for seven years, many Manipuri men were killed and many were taken as Prisoners of War by the Burmese forces. Therefore, in the absence of the menfolk, women in Manipur had to bear heavy responsibilities. They had to take care of the household responsibilities, which include the financial maintenance of the household as well. Apart from that, it had become almost compulsory to take part in the social life for all the women of Manipur, which is still in practice even today. The main place for socialization for women was the marketplace (Nupi Keithel) in Imphal. They exchanged ideas and discussed about social issues. Thus, we see that the absence of their menfolk pushed them forward to contribute to the development of their society.

Many scholars have acknowledged the importance of the collective opinion of market women in the affairs of the state. Women are also in full charge of the marketing of both agriculture and industrial products which provides income for the family in the state of Manipur. The qualities of Manipuri women being assertive may be traced back even to the mythological figures like Imoinu, Panthoibi, Leimarel etc. Imoinu is worshipped as a goddess of wealth, she spent her life rendering help to the poor, sincere and hardworking people. Panthoibi and Leimarel are also worth mentioning. Again, Manipuri history is replete with instances of women taking an active role in the political activities even in the times of the Monarchical era. Laisna, the wife of Nongda-Lairel Pakhangba who ascended the throne of Manipur at Kangla in 33A.D was the Head of the Pacha - the Women's Court - which looked after matrimonial and other women-related issues. The Pacha dealt with all cases connected with females, such as adultery, divorce, wife-beating, assault ietc. Another queen of Manipur known for her bravery was, Linthoigambi, wife of Ningthou Khomba, who ruled from 1432 A.D to 1467 A.D. She is known for having fought against the enemies fearlessly in the absence of her husband, Ningthou Khomba, and for successfully maintaining the territorial integrity of Manipur. Manipuri women's political finesse heralded a saga in the history of entire North-East India following Manipuri princess Kuranganayani's marriage to Ahom King Swargadeva. Even during Swargadeva's reign Kuranganayani played a major role in containing palace intrigue. After Swargadeva's death, Kuranganayani displayed exemplary political chicanery and her able administration could secure Ahom kingdom from disintegration. In more recent history, Maharani Kumudini, Gomti (Thambal) played a significant role in sustaining the Manipuri kingdom intact.

Manipuri women, as a group, very often played an active role and participated in the political and social movements of the state. During the Seven Years Devastation 1819-1826 (Chahi Taret Khuntakpa), women played a crucial role in driving out the Burmese from Manipur. They joined in the struggle to liberate Manipur from the hands of the Burmese. Women in Manipur corrected many injustices done by the rulers or by any official of the kingdom. If the policy or programme of the king negatively affected the general interest of the People in Manipur, women appealed to the king to postpone or cancel his order. For instance, during the reign of king Chandrakirti (1750-1836), the king postponed his Samutanba (Elephant hunting programme) till the end of the harvesting season, after women appealed to him to do so. Apart from this, the $20^{\text {th }}$ century witnessed a number of significant instances of women's participation in socio-economic and political uprisings The first Nupi-lan (Women's Uprising) in 1904 and the second Nupi-lan (Women's Uprising) in 1939 were glaring examples of such collective women's participation during the British rule.

The first Nupi-Lan (Women's Uprising) in 1904 was a movement against the order of the Political Agent forcing the men-folk of the valley to bring teakwood and bamboos from Kabow to rebuild the residence of the Assistant 
Superintendent. The order could not be accepted by the people, and as such, some representatives approached the Government to withdraw the order. Manipuri Women demanded to withdraw it. Ultimately, the Britishers were forced to withdraw their order. Many administrative reforms were then made and since then Manipuri women realized their collective potential.

In the year 1939, the second Nupi-Lan broke out due to the suppressive policies of the British. The British Policy of exporting rice outside Manipur and poor products of the rice in Manipur resulted in the scarcity of rice in the Khwairamband Bazaar. Women who were earning their livelihood by hand pounding rice and selling rice in the bazaar were left without any scope for earning. Later, thousands of women marched towards the state secretariat to present their charter of demands. Many women gheraoed the secretariat pressing their demands to issue orders to ban the export of rice immediately. On the next day, a telegram came from the Maharaja sanctioning ban on the export of rice. Still, many women were sent to jail on the charge of revolt against the British rulers. Both the two movements changed the political direction of the state by demanding the introduction of a democratic Government in Manipur.

Manipuri women were deeply affected by the outbreak of the Second World War. Women could not organize properly in social and political matters. After the Second World War, women participated in the popular movement for the introduction of democratic Government led by the Manipur Congress. After the merger of Manipur to the Indian Union in 1949, the delay in granting statehood seems to have caused discontent among the Meiteis who felt that their joining to the Indian Union brought them no political or economic benefits. Therefore, this discontentment gave rise among certain sections of the Youths and a number of insurgent groups emerged thereafter. Many underground organizations emerged to fight for the restoration of "an Independent Manipur". Many encounters were reported between the Security Personnel and the insurgent groups. The government of Manipur began to be concerned about the tense situation and started deploying more and more security forces in the state. The government of Manipur tried to contain the rising insurgency movement by invoking the Provisions of the Armed Forces (Assam and Manipur) Special Powers Act 1958 to the soil of Manipur. In response to the unstable conditions prevailing at that time in Manipur, many women came out to protect innocent people from the killing and violations of Human Rights being carried out by the security forces as well as by the underground outfits. Accordingly, these women's groups came to be known as the Meira Paibis or the Women Human Rights Activists of Manipur. The role of the Meira Paibis varies from time to time. With the continuation of human rights violations in Manipur which has become one of the most serious problems since 1980s, the womenfolk of Manipur valley in the form of Nisha bandh groups who were pioneering prohibition campaigns turned their attention to fight the crimes against the people of Manipur.

\section{WOMEN'S STATUS IN THE SOCIETY OF MANIPUR}

In spite of the major contributions made by the women in Manipur in various fields, the women of Manipur are marginalised and faced discrimination in the patriarchal society of Manipur like in the rest of India. During the pre-Hindu period, there seem to have high status for women in society. The status of women was equal to their male counterparts. In 1715, during the Garib Niwaz (Pamheiba), in Manipur there used to have a Court for women only (Singh, 1978). Women had their own courtship where the women related issues and family matters were resolved at the Maharani court. In the pre-Hindu period, women in Manipur played an important role in religious activities as well. This is evident from the dominance of women in the goddess cult and in 'Lai Haraoba', (a festival for worshipping Pre-Hindu deities). The priestesses are considered much more important than that the roles of the priests (Parrot, 1980) during the festival. 
At the beginning of the 18th century, the People of Manipur adopted Hinduism during the reign of Gharib Niwaz (1709-1748). The practice of Vaishnavism by Meiteis in Manipur is a somewhat modified version with some aspects of the original Vaishnavism.

Some of the points are highlighted below about cultures, rituals and customs that reflect the status of women in Manipur society.

\section{The Wedding Rituals}

The customs and rituals of 'Luhongba'- marriage ceremony has been followed with certain modification of Hindu religion. Formal rituals and functions are performed at the residence of the bride. Ancestral deity, local deities, Sanamahi are worshipped on this day. Both the bride and groom are ritually sanctified on this day. But, we see certain biasness against women in the Manipuri society which reflects in various cultures and norms of the Manipur society.

In the marriage ceremony, there is a ritual called "kainya dan piba" (giving away our daughter), only men (father, brother, uncle or male relatives) will perform it where any women (mother, sister or relatives) will not be allowed to perform this duty. The marriage procession should be led by a female (Jatra Pubi) whose eldest child is a boy. A woman whose eldest child is a girl cannot lead the marriage procession till the bride's place. After the marriage ceremony, the life of a married woman (mou) starts the very day a woman attains "mou-hood". She has to get up early in the morning; no matter it is summer or winter. She is also expected to do all the household chores just to please her husband and in-laws whether she is capable of doing it or not. It is kind of obligatory.

The condition of a working "mou" is even worst whether she is contributing her energy to the economy of the family. No matter what position she holds in the workplace but in the family and society, she remains as "mou". She is still expected to carry on all kinds of household chores even after a tiring day's work outside and expected to give all her earned money or spent entirely for the welfare of the family otherwise she will not be respected in the family or society.

In a Manipuri society, women take the back seat in every public function like marriage ceremonies, feasts, death ceremonies etc. On the marriage day, the husband dines before his wife and she is made to dine from the left-overs of her husband's plate. The pattern has been changed a little bit in modern times like it is done by taking a spoon of food from the used plate and to continue the dinner from her plate. However, the underlying theme is that women should remain under the control of males

\section{The Childbirth}

The birth of a child is welcome to every family in the Manipuri society as in the rest of the world. But, the preferable of a son to be the firstborn in the family is quite omnipresent in society. And the concept of purity and impurity especially to women are seen mainly at the time of childbirth. If a child is born in a family, with the sharing of the good news, it also spread to all the clans that there is yum mangba, (impure of houses), where the particular clan will not do any form of puja for 12 days. Once the baby is born, the mother will also not be allowed to enter the kitchen and other places of the house for almost 45 days. According to the Universal immunization programme, it is said that there should be exclusive breastfeeding up to 6 months. But in Manipur, the culture of first feeding (chak-umba) is still prevailing that if the child is a baby girl, chak-umba will do after completion of four months, but for boys, it will be held after five months. It shows that since childhood girls are often neglected by social norms. Among the meitei society, son preference is strongly seen, if a 
mother happens to have two girl children, parents, in-laws, and relatives will pressure the mother to go for another baby preferring son.

\section{Death Ceremonies}

People used to bury the dead bodies during the earlier times in Manipur. During the reign of Garib Niwaz after Hindunisation, Manipuris especially Meiteis started cremating them. (T.C Hudson, 1908). If a family member died (father or mother), women are not allowed to light the pyre, the role is given only to males. All the clans will be announced as impure till yumsengba ( cleaning of house with holy puja). In fact, there are two important ceremonies that are performed after the death of a person. They are asti sanchey/ laihun and Sorat or Shradh/lanna thouram. Throughout the process of sorat, women play a very important role in showing the pain and sorrow for the demise. Relatives from near and dear ones keep visiting the deceased family; the women of the family will attain the visitors for the whole 13-14 days till the sorat is performed. During the asthi and sorat, there will be puja where all relatives will attribute flowers and money to the deceased photos. In this puja, all the menfolk (more than 40-50 depending) will be allowed to do the attribute first followed by women folk including the elderly women at the end. This culture again shows the marginalisation of women in the Manipuri customs and rituals.

Because of the advance in civilization, besides phanek women started wearing shirts, skirts, jeans, sarees and salwar kameez where the male counterpart wear shirt and pant. Unfortunately, women do not enjoy the taste of different types of dresses especially after getting married and even unmarried women because their dresses are being discussed, discarded and restricted to wear by different insurgency organizations from time to time. In recent trend, in schools and colleges, girls are not allowed to wear skirts so they have to compulsorily change their skirts into phanek ( the traditional wrap-around). However, as far as the dress and ornaments are concerned, most of them are seen in traditional and religious occasions like Lai Haraoba festivals that are worn by women only. Women are the ones who hold back the culture and traditions of Manipur and at the same time, this culture is again giving a very different but unfortunate picture in the status of women in the society of Manipur.

\section{SUGGESTIONS}

- There is a need to empower women in Manipur. The empowerment of women can be done through various policies of the government. But the major plans should be on educating the women in society.

- Serious steps need to be taken up by the government towards women empowerment as women have an active part socially, culturally, politically in all spheres. So it is therefore we cannot blame only males for the oppression caused to women but also the women themselves.

- The male need to make sure that the wife has an equal voice within the family and society at large.

- There is a need to change this gender inequality or biasness in the customs and cultures, especially in Manipuri society. For this, we need to discourage the stereotyping roles of males and females so that both males and females share equal responsibilities of households and so on and we should educate girl child to make them understand their rights. 


\section{CONCLUSIONS}

Thus we can conclude that Women of Manipur contributes major important roles in society and they deserve to be given their due share of respect and dignity in society. They need to be treated on par with their male counterpart. They need to be treated on equal terms by giving them equal respect and dignity in society. The low status of women which reflects in the cultural norms and rituals in the society can only be corrected by empowering them by educating the women and also through certain plans and policies of important role in rectifying the cultural norms and building peace in the Manipuri society. Women's roles in Manipuri society especially in peacebuilding in the last decade highlight the importance of moving women beyond their traditional roles. Women have been playing an important role in various issues in Manipur. These women who have sacrificed their personal lives and dedicated for the states in order to bring peace and harmony have always been at the forefront to solve many problems in the state. All their activities are conducting voluntarily for ages. Thus we can say that the women of Manipur are the saviour of the state of Manipur. The Meira Paibi movement which emerged in the 1980s continues till now in order to protect the people of Manipur. One of their main activities is to safeguard the people from any evils of the society which includes stopping the government. brewing and consuming of alcohols, drugs dealers or abusers, protecting the people from the harassment and killing by the security personal, they have been constantly keeping vigil at night in order to check all these problems in the Manipur. Therefore, Therefore, Empowerment of women is the need of the hour in the Manipuri society like in other parts of the world.

\section{REFERENCES}

1. Dun, E.W., Gazetteer of Manipur(Vivek Publishing House, Delhi,1975)

2. Walter Fernandes, Samjay Barbara, Modernisation and Women's Studies in North Eastern India: An Comparative Study of Six Tribes. (North Eastern Social Research Centre, Gauhati, 2002)

3. Government of India, Census 2011

4. Ksh. Bimola, Manipuri women- A Study, in N. Sanajaoba(Ed_LManipur: Past and Present, Vol.1.(Mittal Publications,Delhi, 1988),

5. Hudson, T. C. 1908, The Meitheis, London. Low Price Publications,

6. Parratt, S. N. 1980. Religion of Manipur, Calcutta: Firma KLM pvt.

7. Pramodini, N. Gender Differences in Meiteiron linguistics of Tibeto-Burman Area Vol.28.1 Spring 2005.

8. Chaki-Sircar, Manjusri, Feminism in a Traditional Society, Shakti Books, New Delhi, 1984).

9. N.Ibobi Singh, The Manipur Administration, Imphal,1976, P.25 in N. Basanta, Socio-Economic Change in Manipur, 18911947,Imphal, 1998.

10. Barot, H. A. R. E. S. H., and K. U. N. D. A. N. Patel. "Agriculture Finance in India-Issues \& Future Perspectives." International Journal of Business and General Management 4.6: 5-10.

11. Kazemian, Bahram, and Somayyeh Hashemi. "Nominalizations in scientific and political genres: A systemic functional linguistics perspective." International Journal of Humanities and Social Sciences (IJHSS) 3.2 (2014): 211-228.

12. Saha, S. U. K. A. N. Y. A. "Understanding the stream of consciousness text: a linguistic perspective." International Journal of (2016). International Journal of Linguistics and Literature (IJLL) ISSN(P): 2319-3956; ISSN(E): 2319-3964 21-26 
13. Bakhoum, E. S., G. L. Garas, and M. E. Allam. "Sustainability Perspective of Saw-Gang Granite Waste in Concrete Mixes." International Journal of Civil Engineering (IJCE) 4.5: 1-10.

14. Jamini Devi, Women's Movement in Manipur - Past and Present, Manipur Today, (DIPR,Govt. of Manipur,Imphal, 26th January 1999).

15. Singh, M. Chandra (ed). 1963. Panthoibi Khongun, Imphal: Manipur Sahitya Parisad

16. Singh, N. Khelchandra. 1978. Ariba Manipuri Longei. Imphal Manipur State Kala Academy.

17. Tineshowri. M (2010), Reproductive Health and Adolescent Girls, Akansha Publication, New Delhi. 